\title{
PENYEBARAN JAWABAN UJIAN NASIONAL TAHUN 2014 DI SATUAN PENDIDIKAN DITINJAU DARI UNDANG-UNDANG NOMOR 14 TAHUN 2008 TENTANG KETERBUKAAN INFORMASI PUBLIK
}

\author{
Yiska Marva Rohi. ${ }^{1}$ Thea Yori Mataheru. ${ }^{2}$ Evita Monica Chrysan. ${ }^{3}$ \\ Program Pascasarjana Fakultas Hukum Universitas Airlangga \\ Jl. Dharmawangsa Dalam Selatan, Surabaya, Indonesia. \\ Email: thea.yori@gmail.com
}

\begin{abstract}
National examination is an evaluation of student learning outcome at the end of each education level such as elementary, junior, or senior high school with the purpose of measuring the student's competence. Therefore, many regulations such as Law Number 14 of 2008, Law Number 20 of 2003, and all of the related regulations require the National Examination be confidential, so any forms of distribution or leaking of the National Examination questions or answers are strictly prohibited. This study aims to analyze the concept of National Examination in relation to the education evaluation as exempted public information. This study used a Normative-Juridical method using case approach. The results of the study show that National Examination must be kept confidental and secured, so all forms of distribution of leaking of the test questions and answers are prohibited. In other words, the questions and answers of the National Examination are exempted public information, so teachers who distribute the questions and answers can be criminally charged based on Law Number 14 of 2008 on Public Information Disclosure.
\end{abstract}

Keywords : National Examination Answer Key, Exempted Information, Education

\begin{abstract}
ABSTRAK
Ujian Nasional merupakan evaluasi hasil belajar peserta didik pada jenjang akhir pendidikan, baik pada akhir jenjang SD, SMP, maupun SMA, dengan tujuan mengukur kompetensi para siswa. Oleh karena itu, peraturan perundang-undangan mulai dari Undang-Undang Nomor 14 Tahun 2008, Undang-Undang Nomor 20 Tahun 2003 beserta segala peraturan di bawahnya mewajibkan agar Ujian Nasional perlu dijaga kerahasiaannya, sehingga segala bentuk penyebaran atau pembocoran soal maupun jawaban Ujian Nasional tidak diperkenankan. Penelitian ini bertujuan untuk menganalisa konsep Ujian Nasional terkait evaluasi pendidikan dan sebagai informasi publik yang dikecualikan. Penelitian ini menggunakan penelitian Yuridis-Normatif, dengan pendekatan kasus (case approach). Hasil penelitian menjelaskan bahwa Ujian Nasional harus dijaga kerahasiaan dan keamanannya, sehingga segala bentuk penyebaran atau pembocoran soal maupun jawaban Ujian Nasional tidak diperkenankan, atau dengan kata lain, soal maupun jawaban Ujian Nasional merupakan informasi yang dikecualikan dan para oknum tenaga pendidik yang melakukan penyebaran soal maupun jawaban dapat dikenai pertanggungjawaban pidana berdasarkan Undang-Undang Nomor 14 Tahun 2008 tentang Keterbukaan Informasi Publik.
\end{abstract}

Kata Kunci: Jawaban Ujian Nasional, Informasi yang Dikecualikan, Pendidikan.

\footnotetext{
${ }^{1}$ Submission: 6 September 2019 I Review-1: 3 Maret 2020 I Review-2: 3 April 2020 I Production: 17 Maret 2020
} 


\section{Pendahuluan}

Penyelenggaraan sistem pendidikan Nasional dimaksudkan untuk mewujudkan masyarakat maju yang berakar pada kebudayaan bangsa serta persatuan nasional yang berwawasan Bhinneka Tunggal Ika berdasarkan Pancasila dan Undang-Undang Dasar $1945 .^{2}$ Seiring perkembangan zaman, pendidikan menjadi suatu hal yang wajib untuk ditempuh oleh setiap warga negara, mulai dari tahapan pendidikan usia dini, dasar, menengah hingga pendidikan tinggi. Oleh karena itu, peranan lembaga-lembaga pendidikan pun menjadi semakin signifikan karena baik sekolah maupun perguruan tinggi, mengemban tugas nasional.

Peranan lembaga pendidikan menjadi signifikan baik dalam fungsinya untuk mengembangkan kemampuan serta meningkatkan mutu kehidupan dan martabat manusia Indonesia, mencerdaskan kehidupan bangsa dan mengembangkan manusia Indonesia seutuhnya.

Pemerintah telah mewajibkan untuk menjalani program pendidikan Wajib Belajar 12 tahun. Hal tersebut dimaksudkan agar kemampuan berpikir anak-anak dapat dikembangkan dan dapat menjadi siswa yang berkompetensi.

Penentuan kompetensi seorang siswa untuk dapat naik ke jenjang pendidikan yang lebih tinggi seperti dari SD (Sekolah Dasar) ke SMP (Sekolah Menengah Pertama), dari SMP ke SMA (Sekolah Menengah Atas) atau ke SMK (Sekolah Menengah Kejuruan), dari SMA ke perguruan tinggi dilaksanakan melalui Ujian Sekolah sebagai bentuk evaluasi pendidikan yang merupakan wujud pengukuran kompetensi siswa. ${ }^{3}$

Standar Nasional Pendidikan sendiri menurut Undang-Undang Nomor 20 Tahun 2003 salah satunya terdiri atas standar kompetensi lulusan dan penilaian pendidikan. Hal tersebut diatur dalam Pasal 35 Undang-Undang Nomor 20 Tahun 2003 yang menentukan:

\footnotetext{
${ }^{2}$ Hadari Nawawi and Mimi Martini, Kebijakan Pendidikan Di Indonesia Ditinjau Dari Sudut Hukum (Pontianak: Gajah Mada University Press, 1994). Hlm. 2

${ }^{3}$ Peraturan Menteri Pendidikan dan Kebudayaan Nomor 66 Tahun 2013 tentang Standar Penilaian Pendidikan
} 
(1) Standar nasional pendidikan terdiri atas standar isi, proses, kompetensi lulusan, tenaga kependidikan, sarana dan prasarana, pengelolaan, pembiayaan, dan penilaian pendidikan yang harus ditingkatkan secara berencana dan berkala.

(2) Standar nasional pendidikan digunakan sebagai acuan pengembangan kurikulum, tenaga kependidikan, sarana dan prasarana, pengelolaan, dan pembiayaan.

(3) Pengembangan standar nasional pendidikan serta pemantauan dan pelaporan pencapaiannya secara nasional dilaksanakan oleh suatu badan standardisasi, penjaminan, dan pengendalian mutu pendidikan.

(4) Ketentuan mengenai standar nasional pendidikan sebagaimana dimaksud pada ayat (1), ayat (2), dan ayat (3) diatur lebih lanjut dengan peraturan pemerintah. ${ }^{4}$

Penjelasan Pasal 35 ayat (1) Undang-Undang Nomor 20 Tahun 2003 menentukan bahwa:

1.1 Standar isi mencakup ruang lingkup materi dan tingkat kompetensi yang dituangkan ke dalam persyaratan tentang kompetensi tamatan, kompetensi bahan kajian, kompetensi mata pelajaran, dan silabus pembelajaran yang harus dipenuhi oleh peserta didik pada jenjang dan jenis pendidikan tertentu.

1.2 Kompetensi lulusan merupakan kualifikasi kemampuan lulusan yang mencakup sikap, pengetahuan, dan keterampilan sesuai dengan standar nasional yang telah disepakati.

1.3 Standar tenaga kependidikan mencakup persyaratan pendidikan prajabatan dan kelayakan, baik fisik maupun mental, serta pendidikan dalam jabatan.

1.4 Standar sarana dan prasarana pendidikan mencakup ruang belajar, tempat berolahraga, tempat beribadah, perpustakaan, laboratorium, bengkel kerja, tempat bermain, tempat berkreasi dan berekreasi, dan sumber belajar lain yang diperlukan untuk menunjang proses pembelajaran, termasuk penggunaan teknologi informasi dan komunikasi.

\footnotetext{
${ }^{4}$ Pasal 35 Undang-Undang Nomor 20 Tahun 2003 tentang Sistem Pendidikan Nasional
} 
1.5 Peningkatan secara berencana dan berkala dimaksudkan untuk meningkatkan keunggulan lokal, kepentingan nasional, keadilan, dan kompetisi antarbangsa dalam peradaban dunia.

Salah satu pertimbangan dalam seleksi masuk ke jenjang pendidikan yang lebih tinggi adalah dengan pemetaan mutu, pembinaan dan pemberian bantuan untuk peningkatan mutu, sehingga Ujian Sekolah maupun Ujian Nasional menjadi bukti bahwa para siswa yang telah lulus dan berkompeten siap untuk menempuh pendidikan yang lebih tinggi, namun pada praktiknya tidak sedikit terdapat beberapa kasus kecurangan yang dilakukan oleh oknum di sekolah seperti mengambil kesempatan untuk menyebarkan jawaban Ujian Nasional atau penyebaran lembar soal ujian sebelum pelaksanaan yang seharusnya.

Seperti kasus penyebaran jawaban Ujian Nasional Tahun 2014 di SMAN $\mathrm{X}$ yang dilakukan oleh oknum guru, yakni $\mathrm{M}, \mathrm{J}, \mathrm{S}$, dan $\mathrm{P}$ atas perintah dari AG selaku kepala SMAN X untuk meluluskan seluruh siswa kelas XII (dua belas) SMAN X. M, J, S, dan P secara diam-diam mengambil beberapa soal ujian nasional yang hendak dibawa ke Polsek X. Adapun SMAN Y menjadi pihak yang menjawab soal-soal dan membagikan kepada setiap SMA Negeri yang bekerjasama dengannya. Jawaban Ujian Nasional tersebut disimpan dalam CD dan dicetak oleh $\mathrm{P}$ untuk dibagikan pada siswa dengan dibantu oleh $\mathrm{J}$ dan $\mathrm{S}$. Akhirnyaseluruh siswa kelas XII (duabelas) SMAN X lulus seluruhnya dengan nilai yang diperkirakan cukup tinggi dan memuaskan. Padahal berdasarkan kesaksian AG, hanya 30\% siswa kelas XII SMAN X yang lulus tryout.

Putusan PN Nomor 27/Pid.B/2015/PN.Lmg menyatakan bahwa M, J, dan S dipidana dengan Pasal 322 ayat (1) jo Pasal 56 ke-2 KUHP sebagai pihak pembantu kejahatan yang sengaja memberi bantuan pada waktu kejahatan dilakukan, dengan pidana penjara selama 8 (delapan) bulan dengan masa percobaan selama 1 (satu) tahun. P yang disidang secara terpisah dari M, J, dan S dipidana dengan Pasal 322 ayat (1) jo Pasal 55 ayat (1) ke-1 KUHP sebagai pihak yang melakukan, yang menyuruh melakukan, dan yang turut serta melakukan perbuatan, juga dengan pidana penjara selama 8 (delapan) bulan 
dengan masa percobaan selama 1 (satu) tahun sesuai dengan yang dinyatakan dalam Putusan PN Nomor 25/Pid.B/2015/PN.Lmg.

Penelitian yang paling mendekati diketahui pernah dilakukan peneliti terdahulu yaitu Sukma Anggraini dari Universitas Surabaya dengan judul Pembocoran Jawaban Ujian Nasional oleh Oknum Guru Ditinjau dari Kitab Undang-Undang Hukum Pidana dan Undang-Undang Nomor 14 Tahun 2005 tentang Guru dan Dosen. Adapun isu hukum yang dikemukakan dalam penelitian ini adalah bahwa pelaku penyebaran jawaban Ujian Nasional (yang juga adalah para guru) tidak hanya dijatuhi hukuman pidana menurut ketentuan Pasal 322 ayat (1) KUHP, tetapi juga perlu dikenakan sanksi administratif menurut ketentuan Pasal 77 ayat (1), (2), dan (5) Undang-Undang Nomor 14 Tahun 2005 dengan mengacu pada ketentuan Pasal 20 Undang-Undang Nomor 14 Tahun 2005 perihal kewajiban guru. ${ }^{5}$

Penelitian lain yang mendekati adalah penelitian yang pernah dilakukan oleh Elmita Irmanila dari Universitas Islam Negeri Sunan Ampel Surabaya yang berjudul Kredibilitas Penyelenggaraan Ujian Nasional Paper Based Test dan Ujian Nasional Computer Based Test pada Mata Pelajaran Matematika Tingkat SMA dan MA. Adapun isu hukum yang dikemukakan dalam penelitian ini adalah cukup banyaknya kekurangan dari Ujian Nasional yang berbasis kertas (Ujian Nasional Paper Based Text), sehingga perlunya diterapkan model lain dalam pelaksanaan Ujian Nasional untuk meminimalisir kecurangan yang banyak terjadi dalam lingkungan pendidikan, yakni dengan diadakannya UN-CBT (Ujian Nasional Computer Based Text), karena pada saat penggandaan bahan atau soal UN-CBT dilakukan secara online dengan internet sehingga lebih bisa diawasi. ${ }^{6}$

${ }^{5}$ Sukma Anggraini, "Pembocoran Jawaban Ujian Nasional Oleh Oknum Guru Ditinjau Dari Kitab Undang-Undang Hukum Pidana Dan Undang-Undang Nomor 14 Tahun 2005 Tentang Guru Dan Dosen" (Surabaya, 2007). Hlm. 39

${ }^{6}$ Elmita Irmanila, "Kredibilitas Penyelenggaraan Ujian Nasional Paper Based Test Dan Ujian Nasional Computer Based Test Pada Mata Pelajaran Matematika Tingkat SMA Dan MA" (Universitas Islam Negeri Sunan Ampel, 2017). Hlm. 4 


\section{Rumusan Masalah}

Berdasarkan latar belakang masalah di atas, maka rumusan masalah dalam penelitian ini yaitu bagaimana konsep Ujian Nasional sebagai evaluasi pendidikan dan informasi publik yang dikecualikan. Kemudian bagaimana pertanggungjawaban pidana $\mathrm{M}, \mathrm{J}, \mathrm{S}$, dan $\mathrm{P}$ sebagai para tenaga pendidik ditinjau dari Undang-Undang Nomor 14 Tahun 2008 tentang Keterbukaan Informasi Publik.

\section{Tujuan Penelitian}

Tujuan penelitian ini adalah untuk menganalisa konsep Ujian Nasional sebagai evaluasi pendidikan dan informasi publik yang dikecualikan. Kemudian menganalisa pertanggungjawaban pidana $\mathrm{M}, \mathrm{J}, \mathrm{S}$, dan $\mathrm{P}$ sebagai para tenaga pendidik ditinjau Undang-Undang Nomor 14 Tahun 2008 tentang Keterbukaan Informasi Publik.

\section{Metode Penelitian}

Jenis penelitian yang digunakan adalah penelitian hukum normatif yang dilakukan dengan cara menelaah berbagai konsep, teori, maupun asas hukum dari literatur, peraturan perundang-undangan, artikel dan dokumen lainnya yang berkaitan dengan kajian isu hukum dalam penelitian ini. ${ }^{7}$

Kajian ini menggunakan pendekatan kasus (case approach). pendekatan kasus adalah pendekatan yang dilakukan dengan cara melakukan telaah terhadap kasus-kasus yang berkaitan dengan isu yang dihadapi yang telah menjadi putusan pengadilan yang telah mempunyai kekuatan hukum yang tetap. ${ }^{8}$ Pendekatan kasus dalam penelitian normatif dapat bertujuan untuk mempelajari penerapan norma hukum yang dilakukan dalam suatu praktik hukum atau praktik peradilan.

${ }^{7}$ Johnny Ibrahim, Teori Dan Metode Penelitian Hukum Normatif (Malang: Bayumedia Publishing, 2005). Hlm. 240

${ }^{8}$ Peter Mahmud Marzuki, Penelitian Hukum (Surabaya: Kencana, 2005). Hlm. 93 
Bahan hukum yang digunakan dalam penelitian ini, antara lain bahan hukum primer dan bahan hukum sekunder. Bahan hukum primer yang digunakan adalah Kitab Undang-Undang Hukum Pidana (KUHP), UndangUndang Nomor 14 Tahun 2008 tentang Keterbukaan Informasi Publik, Undang-Undang Nomor 20 Tahun 2003 tentang Sistem Pendidikan Nasional, Peraturan Pemerintah Nomor 19 Tahun 2005 jo Peraturan Pemerintah Nomor 32 Tahun 2013 tentang Standar Nasional Pendidikan, Peraturan Menteri Pendidikan dan Kebudayaan Nomor 66 Tahun 2013 tentang Standar Penilaian Pendidikan dan Peraturan Menteri Pendidikan dan Kebudayaan Nomor 50 Tahun 2011 tentang Layanan Informasi Publik di Lingkungan Kementerian Pendidikan dan Kebudayaan.

Bahan hukum sekunder yaitu bahan hukum yang bersifat menjelaskan bahan hukum primer. Bahan hukum sekunder yang dipakai dalam penulisan ini terdiri atas buku-buku literatur, jurnal, artikel dari berbagai sumber, dan karya ilmiah para sarjana yang memiliki keterkaitan dengan objek penelitian.

Teknik pengumpulan bahan hukum yang dilakukan adalah model studi kepustakaan (library research) yaitu pengkajian informasi tertulis mengenai hukum yang berasal dari berbagai sumber dan dipublikasikan secara luas serta dibutuhkan dalam penelitian hukum normatif". 9

Analisis data dalam penelitian ini dilakukan secara kualitatif, yakni data yang dianalisis akan dikemukan dalam bentuk uraian secara sistematis dengan menjelaskan hubungan antar jenis data. Selanjutnya semua data diseleksi dan diolah kemudian dinyatakan secara deskriptif sehingga selain menggambarkan dan mengungkapkan dasar hukumnya juga dapat memberikan solusi terhadap permasalahan yang dimaksud. ${ }^{10}$

\footnotetext{
${ }^{9}$ Ibrahim, Teori Dan Metode Penelitian Hukum Normatif. Hlm. 392

${ }^{10}$ Jimly Asshiddiqie, Teori \& Aliran Penafsiran Hukum Tata Negara (Jakarta: Ind. Hill.Co,
} 1997). Hlm. 17 


\section{Hasil Penelitian dan Pembahasan}

\subsection{Konsep Ujian Nasional sebagai Evaluasi Pendidikan dan Informasi Publik yang Dikecualikan.}

Ujian Nasional sebagai kegiatan evaluasi merupakan jalan terakhir bagi para siswa agar mereka dapat dinilai mampu meneruskan ke jenjang pendidikan yang lebih tinggi. Ujian Nasional adalah upaya pemerintah untuk mengevaluasi tingkat pendidikan secara nasional dengan menetapkan standarisasi nasional pendidikan. Hasil dari Ujian Nasional yang diselenggarakan oleh Negara adalah upaya pemetaan masalah pendidikan dalam rangka menyusun kebijakan pendidikan nasional. ${ }^{11}$

Pengawasan ekstra terhadap anak, baik secara pribadi maupun sebagai bagian dari masyarakat perlu dilakukan untuk melindungi hak-hak anak serta mencegah masuknya pengaruh negatif yang dapat mengganggu tumbuh kembang anak. ${ }^{12}$ Perlindungan hak anak pada hakikatnya menyangkut langsung pengaturan dalam peraturan perundang-undangan. Kebijaksanaan, usaha dan kegiatan yang menjamin terwujudnya perlindungan hak-hak anak itu didasarkan atas pertimbangan bahwa anakanak merupakan golongan rentan dan dependent. ${ }^{13}$ Jika dikaitkan dengan Ujian Nasional, maka Ujian Nasional dapat dikatakan sebagai wujud dari pemenuhan hak anak dalam hal pendidikan.

Ujian Nasional keberadaannya pun telah diatur dalam Peraturan Menteri Pendidikan dan Kebudayaan Nomor 66 Tahun 2013 tentang Standar Penilaian Pendidikan (selanjutnya disingkat Peraturan Menteri Pendidikan dan Kebudayaan Nomor 66 Tahun 2013): "Ujian Nasional, yang selanjutnya disebut UN, adalah kegiatan pengukuran kompetensi tertentu yang dicapai peserta didik dalam rangka menilai pencapaian Standar Nasional Pendidikan, yang dilaksanakan secara nasional."

${ }^{11}$ H. A. R. Tilaar, Standarisasi Pendidikan Nasional: Suatu Tinjauan Kritis (Jakarta: Rineka Cipta, 2006). Hlm. 109-110

${ }^{12}$ Hardjon, Perlindungan Hukum Terhadap Anak (Jakarta: Eresco, 2007). Hlm. 5

13 Maidin Gultom, Perlindungan Hukum Terhadap Anak Dan Perempuan (Bandung: Refika Aditama, 2012). Hlm. 97 
Peraturan Menteri Pendidikan dan Kebudayaan Nomor 66 Tahun 2013 saat ini telah dicabut dan dinyatakan tidak berlaku dengan dikeluarkannya Peraturan Menteri Pendidikan dan Kebudayaan Nomor 23 Tahun 2016, tetapi dalam Peraturan Menteri Pendidikan dan Kebudayaan Nomor 23 Tahun 2016 tidak diatur perihal pengertian Ujian Nasional secara lebih rinci. Selanjutnya, Undang-Undang Nomor 20 Tahun 2003 pada Pasal 35 menjabarkan lebih lanjut perihal Standar Nasional Pendidikan, yang menentukan:

(1) Standar nasional pendidikan terdiri atas standar isi, proses, kompetensi lulusan, tenaga kependidikan, sarana dan prasarana, pengelolaan, pembiayaan, dan penilaian pendidikan yang harus ditingkatkan secara berencana dan berkala.

(2) Standar nasional pendidikan digunakan sebagai acuan pengembangan kurikulum, tenaga kependidikan, sarana dan prasarana, pengelolaan, dan pembiayaan.

(3) Pengembangan standar nasional pendidikan serta pemantauan dan pelaporan pencapaiannya secara nasional dilaksanakan oleh suatu badan standardisasi, penjaminan, dan pengendalian mutu pendidikan. ${ }^{14}$

Terkait Pasal 35 Undang-Undang Nomor 20 Tahun 2003, yang menjadi fokus utama terkait kasus yang dikaji adalah standar kompetensi lulusan dan penilaian pendidikan. Kemudian Pasal 58 ayat (2) UndangUndang Nomor 20 Tahun 2003 menentukan: "Evaluasi peserta didik, satuan pendidikan, dan program pendidikan dilakukan oleh lembaga mandiri secara berkala, menyeluruh, transparan, dan sistemik untuk menilai pencapaian Standar Nasional Pendidikan."

Standar Kompetensi Lulusan dalam Peraturan Pemerintah Nomor 19 Tahun 2005 jo Peraturan Pemerintah Nomor 32 Tahun 2013 tentang Standar Nasional Pendidikan (selanjutnya disingkat Peraturan Pemerintah Nomor 19 Tahun 2005 jo Peraturan Pemerintah Nomor 32 Tahun 2013) diatur pada Pasal 25 hingga Pasal 27, dimana Pasal 26 ayat (1) dan (2) menentukan:

\footnotetext{
${ }^{14}$ Pasal 35 Undang-Undang Nomor 20 Tahun 2003 tentang Sistem Pendidikan Nasional
} 
(1) Standar kompetensi lulusan pada jenjang pendidikan dasar bertujuan untuk meletakkan dasar kecerdasan, pengetahuan, kepribadian, ahklak mulia, serta, keterampilan untuk hidup mandiri dan mengikuti pendidikan lebih lanjut.

(2) Standar kompetensi lulusan pada satuan pendidikan menengah umum bertujuan untuk meningkatkan kecerdasan, pengetahuan, kepribadian, ahklak mulia, serta keterampilan untuk hidup mandiri dan mengikuti pendidikan lebih lanjut.

Perihal Standar Penilaian Pendidikan sebagai salah satu bagian dari Standar Nasional Pendidikan diatur pada Pasal 63 hingga Pasal 72 Peraturan Pemerintah Nomor 19 Tahun 2005 jo Peraturan Pemerintah Nomor 32 Tahun 2013. Pasal 63 ayat (1) menentukan bahwa penilaian pendidikan terdiri atas Penilaian Hasil Belajar oleh Pendidik, Penilaian Hasil Belajar oleh Satuan Pendidikan dan Penilaian Hasil Belajar oleh Pemerintah, dimana Pasal 66 menentukan bahwa Ujian Nasional termasuk dalam Penilaian Hasil Belajar oleh Pemerintah untuk menilai pencapaian kompetensi lulusan secara nasional pada mata pelajaran tertentu dalam kelompok mata pelajaran ilmu pengetahuan teknologi.

Hal tersebut menunjukkan bahwa pelaksanaan Ujian Nasional penting untuk mengukur kemampuan siswa sebelum mereka naik ke jenjang pendidikan yang lebih tinggi dalam rangka persiapan agar para siswa dapat siap untuk mendapatkan materi dengan tingkat kerumitan yang lebih tinggi. Kemudian Peraturan Menteri Pendidikan dan Kebudayaan Nomor 50 Tahun 2011 pada Pasal 12 ayat (3) huruf f menentukan: "Informasi yang dikecualikan terdiri atas: Informasi yang bersifat rahasia yang digunakan untuk mengetahui penilaian prestasi peserta didik, dan soal ujian dalam penyaringan penerimaan pegawai negeri sipil," yang menegaskan bahwa jawaban Ujian Nasional adalah suatu hal yang bersifat rahasia sebagai informasi untuk mengetahui penilaian prestasi peserta didik. 
Undang-Undang Nomor 14 Tahun 2008 tentang Keterbukaan Informasi Publik (selanjutnya disebut Undang-Undang Nomor 14 Tahun 2008) mengatur perihal jenis-jenis Informasi Publik di Indonesia, mulai dari Informasi yang Wajib Disediakan dan Diumumkan dan Informasi yang Dikecualikan. Informasi yang Wajib Disediakan dan Diumumkan terdiri atas Informasi yang Wajib Disediakan dan Diumumkan Secara Berkala (Pasal 9), Informasi yang Wajib Diumumkan secara Serta Merta (Pasal 10) dan Informasi yang Wajib Tersedia Setiap Saat (Pasal 11).

Informasi Publik sebagai hal yang paling disorot dalam penulisan ini menjadi suatu hal yang berhak diketahui setiap orang, apalagi kebebasan memperoleh informasi telah diatur dalam UUD 1945. Namun faktanya terdapat pula tantangan yang harus dihadapi dalam kebebasan memperoleh informasi publik, yakni "berkenaan dengan paradigma rahasia negara sebagai pengecualian dari informasi public". ${ }^{15}$ Artinya, sebebas-bebasnya orang memperoleh informasi, tetaplah terdapat batasan dalam hal perolehan informasi karena terdapat pula informasi yang dikecualikan atau tidak diungkapkan pada khalayak.

Dalam Pasal 17 Undang-Undang Nomor 14 Tahun 2008 sesungguhnya telah mengatur perihal jenis-jenis Informasi yang Dikecualikan:

Setiap Badan Publik wajib membuka akses bagi setiap Pemohon Informasi Publik untuk mendapatkan Informasi Publik, kecuali:

a. Informasi Publik yang apabila dibuka dan diberikan kepada Pemohon Informasi Publik dapat menghambat proses penegakan hukum, yaitu informasi yang dapat:

1. Menghambat proses penyelidikan dan penyidikan suatu tindak pidana;

2. Mengungkapkan identitas informan, pelapor, saksi, dan/atau korban yang mengetahui adanya tindak pidana;

3. Mengungkapkan data intelijen kriminal dan rencana-rencana yang berhubungan dengan pencegahan dan penanganan segala bentuk kejahatan transnasional;

\footnotetext{
${ }^{15}$ Muhammad Mihradi, Kebebasan Informasi Publik Versus Rahasia Negara (Jakarta: Ghalia Indonesia, 2011). Hlm. 7
} 
4. Membahayakan keselamatan dan kehidupan penegak hukum dan/atau keluarganya; dan/atau

5. Membahayakan keamanan peralatan, sarana, dan/atau prasarana penegak hukum.

b. Informasi Publik yang apabila dibuka dan diberikan kepada Pemohon Informasi Publik dapat mengganggu kepentingan perlindungan hak atas kekayaan intelektual dan perlindungan dari persaingan usaha tidak sehat;

c. Informasi Publik yang apabila dibuka dan diberikan kepada Pemohon Informasi Publik dapat membahayakan pertahanan dan keamanan negara, yaitu:

1. Informasi tentang strategi, intelijen, operasi, taktik dan teknik yang berkaitan dengan penyelenggaraan sistem pertahanan dan keamanan negara, meliputi tahap perencanaan, pelaksanaan dan pengakhiran atau evaluasi dalam kaitan dengan ancaman dari dalam dan luar negeri;

2. Dokumen yang memuat penyelenggaraan sistem pertahanan dan keamanan negara yang meliputi tahap perencanaan, pelaksanaan dan pengakhiran atau evaluasi;

3. Jumlah, komposisi, disposisi, atau dislokasi kekuatan dan kemampuan dalam penyelenggaraan sistem pertahanan dan keamanan negara serta rencana pengembangannya;

4. Gambar dan data tentang situasi dan keadaan pangkalan dan/atau instalasi militer;

5. Data perkiraan kemampuan militer dan pertahanan negara lain terbatas pada segala tindakan dan/atau indikasi negara tersebut yang dapat membahayakan kedaulatan negara kesatuan republik indonesia dan/atau data terkait kerjasama militer dengan negara lain yang disepakati dalam perjanjian tersebut sebagai rahasia atau sangat rahasia;

6. Sistem persandian negara; dan/atau

7. Sistem intelijen negara.

d. Informasi Publik yang apabila dibuka dan diberikan kepada Pemohon Informasi Publik dapat mengungkapkan kekayaan alam Indonesia;

e. Informasi Publik yang apabila dibuka dan diberikan kepada Pemohon Informasi Publik, dapat merugikan ketahanan ekonomi nasional:

1. Rencana awal pembelian dan penjualan mata uang nasional atau asing, saham dan aset vital milik negara;

2. Rencana awal perubahan nilai tukar, suku bunga, dan model operasi institusi keuangan;

3. Rencana awal perubahan suku bunga bank, pinjaman pemerintah, perubahan pajak, tarif, atau pendapatan negara/daerah lainnya;

4. Rencana awal penjualan atau pembelian tanah atau properti; 
5. Rencana awal investasi asing;

6. Proses dan hasil pengawasan perbankan, asuransi, atau lembaga keuangan lainnya; dan/atau

7. Hal-hal yang berkaitan dengan proses pencetakan uang.

f. Informasi Publik yang apabila dibuka dan diberikan kepada Pemohon Informasi Publik, dapat merugikan kepentingan hubungan luar negeri:

1. Posisi, daya tawar dan strategi yang akan dan telah diambil oleh negara dalam hubungannya dengan negosiasi internasional;

2. Korespondensi diplomatik antarnegara;

3. Sistem komunikasi dan persandian yang dipergunakan dalam menjalankan hubungan internasional; dan/atau

4. Perlindungan dan pengamanan infrastruktur strategis indonesia di luar negeri.

g. Informasi Publik yang apabila dibuka dapat mengungkapkan isi akta otentik yang bersifat pribadi dan kemauan terakhir ataupun wasiat seseorang;

h. Informasi Publik yang apabila dibuka dan diberikan kepada Pemohon Informasi Publik dapat mengungkap rahasia pribadi, yaitu:

1. Riwayat dan kondisi anggota keluarga;

2. Riwayat, kondisi dan perawatan, pengobatan kesehatan fisik, dan psikis seseorang;

3. Kondisi keuangan, aset, pendapatan, dan rekening bank seseorang;

4. Hasil-hasil evaluasi sehubungan dengan kapabilitas, intelektualitas, dan rekomendasi kemampuan seseorang; dan/atau

5. Catatan yang menyangkut pribadi seseorang yang berkaitan dengan kegiatan satuan pendidikan formal dan satuan pendidikan non formal

i. Memorandum atau surat-surat antar Badan Publik atau intra Badan Publik, yang menurut sifatnya dirahasiakan kecuali atas putusan Komisi Informasi atau pengadilan;

j. Informasi yang tidak boleh diungkapkan berdasarkan UndangUndang.

Jawaban Ujian Nasional sesungguhnya juga dapat digolongkan sebagai suatu bentuk arsip. Apabila dikaitkan dengan Undang-Undang Nomor 43 Tahun 2009 tentang Kearsipan, maka jawaban Ujian Nasional sesungguhnya memenuhi unsur dalam Pasal 44 ayat (1) huruf i, yang menentukan: "Pencipta arsip dapat menutup akses atas arsip dengan alasan apabila arsip dibuka untuk umum dapat: mengungkap memorandum atau 
surat-surat yang menurut sifatnya perlu dirahasiakan." Unsur-unsur dari Pasal 44 ayat (1) huruf i meliputi:

5.1.1. Unsur Pencipta arsip, dimana menurut Putusan Komisi Informasi Pusat No. 331/IX/KIP-PS-A/2013, pencipta arsip adalah BSNP sebagai pihak yang ditugaskan oleh Pemerintah untuk menyelenggarakan Ujian Nasional.

5.1.2. Unsur Menutup akses atas arsip, dimana BSNP sebagai pencipta arsip wajib menutup akses atas arsip berupa naskah soal dan jawaban Ujian Nasional.

5.1.3. Unsur Dengan alasan apabila arsip dibuka untuk umum dapat mengungkap memorandum atau surat yang menurut sifatnya perlu dirahasiakan, dimana dalam hal ini, soal maupun jawaban Ujian Nasional dapat dikatakan termasuk sebagai "surat, dimana soal dan jawaban Ujian Nasional merupakan informasi tertulis berupa rekaman kegiatan evaluasi yang dibuat dengan syarat agar dirahasiakan atau tidak disebarkan pada para peserta didik". ${ }^{16}$ Terutama jawaban Ujian Nasional sebagai instrumen untuk melakukan penilaian prestasi belajar para siswa. Soal dan jawaban Ujian Nasional pun memerlukan pengamanan agar tidak terjadi pembocoran tanpa izin agar dapat berdaya guna dalam kegiatan evaluasi peserta didik yang diselenggarakan oleh Pemerintah.

Kenyataannya, baik Peraturan Menteri Pendidikan dan Kebudayaan Nomor 50 Tahun 2011, Undang-Undang Nomor 20 Tahun 2003, maupun Undang-Undang Nomor 43 Tahun 2009 tidak mengatur perihal sanksi bagi siapapun yang berusaha mengakses atau menyebarkan informasi yang dikecualikan maupun pihak lain selain pencipta arsip yang berusaha mengakses suatu arsip yang bersifat rahasia untuk disebarluaskan. Sanksi

${ }^{16}$ Lamuddin Finoza, Komposisi Bahasa Indonesia Uuntuk Mahasiswa Nonjurusan Bahasa (Jakarta: Diksi Insan Mulia, 2005). Hlm. 181 
berupa ketentuan pidana bagi siapapun yang berusaha mengakses atau menyebarkan informasi yang dikecualikan maupun arsip yang harus dirahasiakan ini diatur dalam Undang-Undang Nomor 14 Tahun 2008 tentang Keterbukaan Informasi Publik dalam Pasal 54 ayat (1), yang menentukan:

Setiap Orang yang dengan sengaja dan tanpa hak mengakses dan/atau memperoleh dan/atau memberikan informasi yang dikecualikan sebagaimana diatur dalam Pasal 17 huruf a, huruf $b$, huruf $\mathrm{d}$, huruf $\mathrm{f}$, huruf $\mathrm{g}$, huruf $\mathrm{h}$, huruf $\mathrm{i}$, dan huruf $\mathrm{j}$ dipidana dengan pidana penjara paling lama 2 (dua) tahun dan pidana denda paling banyak Rp 10.000.000,00 (sepuluh juta rupiah). ${ }^{17}$

Unsur-unsur dari Pasal 54 ayat (1) meliputi:

5.1.1. Unsur Setiap Orang.

Unsur setiap Orang memiliki pengertian yang hampir serupa dengan "barangsiapa", yakni siapa saja, baik laki-laki maupun perempuan yang dapat menjadi subjek hukum atau pelaku tindak pidana, yang dapat dikenakan pertanggungjawaban pidana karena kejiwaannya tidak terganggu sebagaimana telah dijelaskan di atas.

5.1.2. Unsur dengan sengaja dan tanpa hak.

Unsur dengan sengaja berarti perbuatan yang benar-benar disadari, diketahui, dan dikehendaki oleh si pelaku, sedangkan tanpa hak berarti sesungguhnya pelaku tidak diperkenankan karena tidak berhak melakukan suatu perbuatan yang dilarang.

5.1.3. Unsur mengakses dan/atau memperoleh dan/atau memberikan informasi yang dikecualikan sebagaimana diatur dalam Pasal 17 huruf a, huruf $b$, huruf $d$, huruf $f$, huruf $g$, huruf $h$, huruf $i$, dan huruf $j$.

5.1.4. Unsur ini bersifat gabungan, yakni bisa kumulatif (dan) maupun alternatif (atau).

${ }^{17}$ Pasal 54 ayat (1) Undang-Undang Nomor 14 Tahun 2008 tentang Keterbukaan Informasi 
Peraturan Menteri Pendidikan dan Kebudayaan Nomor 97 Tahun 2013 bahkan menegaskan bahwa Ujian Nasional wajib dijaga kejujuran dan kerahasiaannya dalam Pasal 19 yang menentukan: "Orang perseorangan, kelompok, dan/atau lembaga yang terlibat dalam pelaksanaan Ujian Nasional wajib menjaga kejujuran, kerahasiaan, keamanan, dan kelancaran pelaksanaan Ujian Nasional." Apabila terdapat pihak yang tidak menjaga kejujuran dan kerahasiaan Ujian Nasional, maka Pasal 27 ayat (1) menentukan: "Orang perseorangan, kelompok, dan/atau lembaga yang terbukti secara sah melakukan pelanggaran sebagaimana dimaksud dalam Pasal 19 akan diproses dan dikenakan sanksi sesuai ketentuan peraturan perundang-undangan." Berdasarkan Pasal 27 ayat (1) Peraturan Menteri Pendidikan dan Kebudayaan Nomor 97 Tahun 2013, maka dapat disimpulkan bahwa siapapun yang tidak menjaga kejujuran, kerahasiaan, keamanan dan kelancaran Ujian Nasional dapat dikenakan sanksi berdasarkan ketentuan peraturan perundang-undangan yang terkait.

\subsection{Pertanggungjawaban Pidana $M, J, S$, dan $P$ sebagai para tenaga pendidik ditinjau dari Undang-Undang Nomor 14 Tahun 2008 tentang Keterbukaan Informasi Publik.}

Jika mencermati kasus yang telah dijelaskan di atas, maka jelas bahwa M, J, S, dan P selaku guru dari SMAN X tidak perdulidengan tujuan dari pelaksanaan Ujian Nasional yang seharusnya adalah untuk mengasah kemampuan berpikir siswa perihal materi yang telah mereka dapatkan selama mereka bersekolah serta agar siswa dapat dikatakan mampu untuk menempuh jenjang pendidikan yang lebih tinggi.

Pada praktiknya $\mathrm{M}, \mathrm{J}, \mathrm{S}$, dan $\mathrm{P}$ justru melakukan penyebaran jawaban Ujian Nasional dengan maksud agar para siswa tidak perlu kesulitan mempelajari materi yang dipandang terlalu banyak, tidak perlu berpikir terlalu lama dalam mengerjakan Ujian Nasional dan tentunya agar seluruh siswa kelas XII SMAN X dapat lulus Ujian Nasional. 
Apabila perbuatan $\mathrm{M}, \mathrm{J}, \mathrm{S}$, dan $\mathrm{P}$ ditinjau dari unsur-unsur yang terkandung dalam Pasal 54 ayat (1) Undang-Undang Nomor 14 Tahun 2008 tentang Keterbukaan Informasi Publik sebagaimana yang telah dijelaskan di atas, maka dapat diuraikan sebagai berikut:

\subsubsection{Unsur Setiap Orang.}

Dalam kasus ini, M, J, S, dan $\mathrm{P}$ merupakan para pelaku tindak pidana pembukaan informasi yang bersifat rahasia. Berdasarkan hal tersebut, maka unsur setiap orang telah terpenuhi.

5.2.2. Unsur dengan sengaja dan tanpa hak.

M, J, S, dan P secara sadar menyanggupi perintah dari AG untuk menyebarkan jawaban Ujian Nasional Tahun 2014, dimana $\mathrm{M}, \mathrm{J}, \mathrm{S}$, dan $\mathrm{P}$ setelah mendapat perintah dari AG akhirnya menghendaki agar para siswa mengerjakan soal Ujian Nasional dengan cara curang, yakni tanpa belajar dan langsung menjawab dengan kunci jawaban yang diberikan karena dengan demikian, para siswa diyakini dapat lulus tanpa perlu usaha keras belajar dengan bahan-bahan ujian yang ditakutkan belum tentu sama dengan soal-soal yang akan dikeluarkan dalam Ujian Nasional. Perbuatan untuk melakukan kecurangan tersebut benar-benar disadari dan dikehendaki oleh $\mathrm{M}, \mathrm{J}, \mathrm{S}$, dan $\mathrm{P}$ dan $\mathrm{M}, \mathrm{J}, \mathrm{S}$, dan $\mathrm{P}$ yang secara tanpa hak melakukan penyebaran jawaban Ujian Nasional, dimana seharusnya yang berhak untuk menentukan apakah layak dilakukan penyebaran soal maupun jawaban Ujian Nasional tentunya adalah pihak penyelenggaran Ujian Nasional, yakni BSNP, dan juga Kementerian Pendidikan dan Kebudayaan. Berdasarkan hal itu, unsur dengan sengaja dan tanpa hak telah terpenuhi. 
5.2.3. Unsur mengakses dan/atau memperoleh dan/atau memberikan informasi yang dikecualikan sebagaimana diatur dalam Pasal 17 huruf a, huruf b, huruf d, huruf f, huruf g, huruf $h$, huruf $i$, dan huruf $j$.

Jika dikaitkan dengan kasus yang dibahas, maka M, J, S, dan P telah berusaha memperoleh naskah soal Ujian Nasional yang seharusnya bersifat rahasia dan kemudian memberikan atau menyebarluaskan kunci jawaban Ujian Nasional kepada para siswa SMAN X. Penyebaran jawaban Ujian Nasional sebagaimana di atas termasuk memenuhi unsur dalam Pasal 17 huruf j, yakni "Informasi yang tidak boleh diungkapkan berdasarkan undang-undang." Undang-undang yang dimaksud dalam hal ini yakni Undang-Undang Nomor 20 Tahun 2003 (Pasal 35 ayat (1) dan Pasal 58 ayat (2)) dan Undang-Undang Nomor 43 Tahun 2009 (Pasal 44 ayat (1) huruf i), yang kemudian diperkuat pula dengan adanya Peraturan Pemerintah Nomor 19 Tahun 2005 jo Peraturan Pemerintah Nomor 32 Tahun 2013, Peraturan Menteri Pendidikan dan Kebudayaan Nomor 50 Tahun 2011, Peraturan Menteri Pendidikan dan Kebudayaan Nomor 66 Tahun 2013, dan juga Peraturan Menteri Pendidikan dan Kebudayaan Nomor 97 Tahun 2013 sebagai sekumpulan peraturan perundangundangan yang saling terkait atau berbuntut satu dengan yang lain. Berdasarkan hal tersebut, maka unsur "mengakses dan/atau memperoleh dan/atau memberikan informasi yang dikecualikan berdasarkan Pasal 17", dalam hal ini Pasal 17 huruf $\mathrm{j}$, telah terpenuhi.

Jika memperhatikan segala yang telah dijabarkan, maka berdasarkan Pasal 27 ayat (1) Peraturan Menteri Pendidikan dan Kebudayaan Nomor 97 Tahun 2013, M, J, S, dan P telah melakukan pelanggaran karena tidak menjaga kejujuran dan kerahasiaan Ujian Nasional sehingga dapat dikenakan sanksi sesuai ketentuan peraturan perundang-undangan, dalam hal ini yakni Undang-Undang Nomor 14 Tahun 2008. Dengan demikian, unsur Pasal 27 ayat (1) tersebut telah terpenuhi. 
M, J, S, dan P selain itu juga melakukan penyertaan (deelneming) dalam perbuatan mereka. $M$ telah menjadi pembantu kejahatan (medeplichtige) sebagaimana diatur dalam Pasal 56 ke-2 KUHP karena M telah dengan sengaja memberi kesempatan atau sarana untuk melakukan kejahatan dengan mengambil beberapa naskah soal Ujian Nasional Tahun 2014 dari dalam salah satu mobil yang hendak membawa naskah-naskah soal Ujian Nasional untuk disimpan di Polsek X, dengan tujuan akhir untuk menyebarkan jawaban Ujian Nasional.

M telah membuka kesempatan terlaksananya tindak pidana terkait pengungkapan informasi yang dikecualikan berupa pengungkapan jawaban Ujian Nasional. $M$ bukanlah pembantu pada saat kejahatan dilakukan, karena pada saat $\mathrm{M}$ mengambil naskah soal Ujian Nasional secara diam-diam sebagai bentuk bantuan, kejahatan berupa penyebaran informasi yang dikecualikan itu belum dilakukan atau belum terjadi.

J selaku terdakwa II dalam hal ini dapat dikatakan merangkap menjadi pembantu kejahatan (medeplichtige) dan pihak yang turut serta melakukan perbuatan (mede pleger). Sebagai pembantu kejahatan, J membantu M untuk mengambil beberapa naskah soal Ujian Nasional secara diam-diam yang sama dengan memberikan kesempatan, sarana atau bantuan agar rangkaian perbuatan awal yang berujung pada penyebaran jawaban Ujian Nasional tersebut dapat terlaksana dengan mudah. Sebagai pihak yang turut serta melakukan perbuatan, J dalam keterangan terdakwa diketahui juga turut serta dalam membagikan jawaban Ujian Nasional kepada para siswa selama pelaksanaan Ujian Nasional, bersama dengan beberapa guru lainnya.

S selaku terdakwa III dalam putusan yang sama pun juga dapat dikatakan merangkap sebagai pembantu kejahatan (medeplichtige) dan sebagai pihak yang turut serta melakukan perbuatan (mede pleger). Sebagai pembantu kejahatan, S membantu M dan J untuk memasukkan beberapa naskah soal yang berhasil diambil oleh M dan J ke dalam sebuah tas ransel hitam untuk segera dibawa ke SMAN Y. Kemudian S melapor 
kepada P bahwa soal-soal Ujian Nasional telah berhasil diambil dan keduanya bersama-sama mengantar soal-soal Ujian Nasional tersebut ke SMAN Y bersama 2 guru lainnya. Sebagai pihak yang turut serta melakukan perbuatan (mede pleger), $\mathrm{S}$ bersama dengan $\mathrm{P}, \mathrm{F}$, dan $\mathrm{W}$ mengantarkan soal-soal Ujian Nasional yang telah diambil secara diamdiam itu ke SMAN Y untuk diperiksa kesamaan varian soalnya dengan varian soal Ujian Nasional yang diterima oleh SMAN Y. Kemudian, selama beberapa hari pelaksanaan Ujian Nasional, S bersama dengan P, J, dan F membagikan lembaran-lembaran kertas berisi jawaban Ujian Nasional kepada para siswa dengan cara meletakkan di dekat pintu kelas agar mudah diambil oleh para siswa.

Apabila dikaitkan dengan Pasal 54 ayat (1) Undang-Undang Nomor 14 Tahun 2008, M, J, dan S dapat dikatakan telah memperoleh informasi yang dikecualikan berdasarkan Undang-Undang yang berupa naskah soal Ujian Nasional, dimana tujuan akhir mereka memperoleh naskah soal Ujian Nasional tersebut adalah untuk menyebarkan jawaban Ujian Nasional.

$\mathrm{P}$ yang divonis dalam putusan yang terpisah dari $\mathrm{M}, \mathrm{J}$, dan $\mathrm{S}$ dalam hal ini dapat dikatakan termasuk sebagai pihak yang turut serta melakukan perbuatan (mede pleger) sebagaimana diatur dalam Pasal 55 ayat (1) ke-1 KUHP. P semula mengantarkan beberapa naskah soal Ujian Nasional yang berhasil diambil itu ke SMAN Y bersama dengan F, W, dan terdakwa S untuk diperiksa kesamaan varian soalnya. $\mathrm{P}$ juga melancarkan strategi untuk menyebarkan kunci jawaban Ujian Nasional dengan cara memperoleh CD yang berisikan jawaban Ujian Nasional Tahun 2014 di SMAN Y, dan kemudian P menge-print dan mencetak jawaban Ujian Nasional dalam CD tersebut ke dalam lembaran kertas kecil-kecil agar dapat dibagikan kepada para siswa SMAN X selama pelaksanaan Ujian Nasional. 
P bahkan juga membagikan lembar-lembar jawaban Ujian Nasional Tahun 2014 yang telah dicetaknya itu kepada 6 orang kepala sekolah di Sub Rayon X agar juga dapat dibagikan kepada para siswa di sekolah mereka masing-masing. Kemudian selama beberapa hari pelaksanaan Ujian Nasional, $\mathrm{P}$ bersama dengan $\mathrm{S}$, J, dan $\mathrm{F}$ membagikan lembaranlembaran berisi jawaban Ujian Nasional kepada para siswa sehingga seluruh siswa kelas XII SMAN X lulus dengan nilai tinggi.

Jika dikaitkan dengan Pasal 54 ayat (1) Undang-Undang Nomor 14 Tahun 2008, P sebagai medepleger dapat dikatakan telah memperoleh informasi yang dikecualikan, yakni $\mathrm{P}$ memperoleh $\mathrm{CD}$ yang berisikan jawaban Ujian Nasional yang diberikan oleh SMAN Y yang selanjutnya dicetak oleh P ke dalam lembaran kertas kecil-kecil. Selanjutnya, P juga memberikan informasi yang dikecualikan dalam wujud membagikan jawaban Ujian Nasional kepada para siswa kelas XII SMAN X bersama dengan S, J, dan F, dan P juga memberikan informasi yang dikecualikan dalam wujud membagikan jawaban Ujian Nasional kepada 6 orang kepala sekolah di Sub Rayon X untuk siswa kelas XII di sekolah mereka masingmasing.

AG selaku kepala sekolah dalam hal ini dapat digolongkan sebagai pihak pembujuk (uitlokker), dikarenakan inisiatif untuk melakukan perbuatan pidana datang dari AG. AG adalah pihak yang mengusulkan agar M, J, S, dan P selaku para guru di SMAN X menyebarkan jawaban Ujian Nasional dengan tujuan agar para siswa kelas XII SMAN X dipastikan dapat lulus Ujian Nasional sehingga tidak menjatuhkan nama baik sekolah, karena saat tryout, diketahui hanya 30\% siswa yang lulus tryout.

Terdapat pula ketentuan yang diatur dalam KUHP mengenai asas legalitas yang berbunyi nullum delictum nulla poena sine praevia lege poenali yang memiliki arti "tiada seorangpun dapat dipidana, kecuali perbuatan yang dilakukan tersebut telah ditetapkan sebagai tindak pidana dalam suatu peraturan perundang-undangan yang berlaku pada saat 
perbuatan itu dilakukan.". ${ }^{18}$ Berdasarkan kasus ini, maka tindakan M, J, S, dan $\mathrm{P}$ telah memenuhi unsur-unsur dalam setiap peraturan perundangundangan yang telah dijabarkan di atas, yakni Undang-Undang Nomor 14 Tahun 2008 dengan mengacu pada Undang-Undang Nomor 20 Tahun 2003, Undang-Undang Nomor 43 Tahun 2009, Peraturan Pemerintah Nomor 19 Tahun 2005 jo Peraturan Pemerintah Nomor 32 Tahun 2013, Peraturan Menteri Pendidikan dan Kebudayaan Nomor 50 Tahun 2011, Peraturan Menteri Pendidikan dan Kebudayaan Nomor 97 Tahun 2013, dan Peraturan Menteri Pendidikan dan Kebudayaan Nomor 66 Tahun 2013 sebagai sekumpulan peraturan perundang-undangan yang saling terkait atau berbuntut satu dengan yang lain, sehingga $\mathrm{M}, \mathrm{J}, \mathrm{S}$, dan P selaku guruguru dari SMAN $\mathrm{X}$ yang telah melakukan tindak pidana pembukaan informasi yang bersifat rahasia atau dikecualikan berupa penyebaran jawaban Ujian Nasional dapat dikenakan pertanggungjawaban pidana berdasarkan Pasal 54 ayat (1) Undang-Undang Nomor 14 Tahun 2008, yakni dengan ancaman pidana penjara paling lama 2 (dua) tahun dan denda paling banyak Rp 10.000.000,00 (sepuluh juta rupiah).

\section{Kesimpulan}

Berdasarkan pembahasan dan analisis sebelumnya maka dapat disimpulkan bahwa Ujian Nasional merupakan evaluasi yang penting bagi para siswa SMA tingkat akhir untuk mengukur kompetensi para siswa untuk menentukan apakah mereka layak untuk lulus dan melanjutkan ke jenjang berikutnya ataukah mereka masih memerlukan pembelajaran ulang agar lebih berkompeten. Maka dari itu, Ujian Nasional perlu dijaga kerahasiaannya agar tidak diketahui oleh para peserta didik agar tujuan Ujian Nasional tersebut dapat tercapai, apalagi telah terdapat beberapa pengaturan perihal kewajiban menjaga kerahasiaan Ujian Nasional, namun pada kenyataannya tetap saja dapat terjadi pembocoran jawaban Ujian Nasional sehingga para siswa hanya

\footnotetext{
${ }^{18}$ Tim Pengajar Hukum Pidana Fakultas Hukum Universitas Surabaya, "Handout Hukum Pidana" (Surabaya, 2015). Hlm. 5
} 
tinggal menjawab Ujian Nasional tanpa membaca dan memahami soal yang ada. Kemudian yang lebih memprihatinkan adalah pembocoran jawaban Ujian Nasional tersebut dilakukan oleh oknum guru, dalam kasus ini yakni M, J, S, dan P. Jika memperhatikan pembahasan tersebut di atas, maka perbuatan yang dilakukan oleh M, J, S, dan P telah memenuhi unsur-unsur dalam Pasal 54 ayat (1) Undang-Undang Nomor 14 Tahun 2008 dengan mengacu pada Pasal 35 ayat (1) dan Pasal 58 ayat (2) Undang-Undang Nomor 20 Tahun 2003, Pasal 44 ayat (1) huruf i Undang-Undang Nomor 43 Tahun 2009, Pasal 66 Peraturan Pemerintah Nomor 19 Tahun 2005 jo Peraturan Pemerintah Nomor 32 Tahun 2013, Pasal 12 ayat (3) huruf f Peraturan Menteri Pendidikan dan Kebudayaan Nomor 50 Tahun 2011.

Lampiran Peraturan Menteri Pendidikan dan Kebudayaan Nomor 66 Tahun 2013 perihal pengertian Ujian Nasional, dan Pasal 27 ayat (1) serta Pasal 19 Peraturan Menteri Pendidikan dan Kebudayaan Nomor 97 Tahun 2013, yakni bahwa M, J, S, dan P dengan sengaja melakukan penyebaran informasi yang dikecualikan berupa jawaban Ujian Nasional yang seharusnya dijaga kerahasiaan dan kejujurannya sebagai salah satu arsip, karena Ujian Nasional merupakan salah satu bentuk evaluasi yang dilakukan dengan tujuan untuk mencapai Standar Nasional Pendidikan berupa Standar Kompetensi Lulusan sebagai bentuk penilaian pendidikan.

Berikutnya, M, J, S, dan P telah melakukan apa yang disebut dengan penyertaan (deelneming). M dapat disebut sebagai pembantu kejahatan (medeplichtige), J diketahui merangkap menjadi pembantu kejahatan dan sekaligus menjadi pihak yang turut serta melakukan (mede pleger), $\mathrm{S}$ juga merangkap menjadi pembantu kejahatan dan juga menjadi pihak yang turut serta melakukan, dan $\mathrm{P}$ adalah pihak yang turut serta melakukan dimana $\mathrm{P}$ memperoleh CD yang berisikan jawaban Ujian Nasional Tahun 2014 di SMAN Y, kemudian P menge-print dan mencetak jawaban Ujian Nasional dari CD itu ke dalam lembaran kertas kecil-kecil agar dapat dibagikan kepada para siswa kelas XII SMAN X selama pelaksanaan Ujian Nasional. 
Kemudian P, bersama dengan beberapa guru lainnya, memberikan jawaban Ujian Nasional kepada para siswa selama pelaksanaan Ujian Nasional. Oleh karena itu, dengan mengacu pada beberapa peraturan perundang-undangan yang terdiri atas Undang-Undang Nomor 14 Tahun 2008 dengan mengacu pada Pasal 35 ayat (1) dan Pasal 58 ayat (2) Undang-Undang Nomor 20 Tahun 2003, Pasal 44 ayat (1) huruf i Undang-Undang Nomor 43 Tahun 2009, Pasal 66 Peraturan Pemerintah Nomor 19 Tahun 2005 jo Peraturan Pemerintah Nomor 32 Tahun 2013, Pasal 12 ayat (3) huruf f Peraturan Menteri Pendidikan dan Kebudayaan Nomor 50 Tahun 2011, Lampiran Permendikud No. 66 Tahun 2013 perihal pengertian Ujian Nasional, dan Pasal 27 ayat (1) serta Pasal 19 Peraturan Menteri Pendidikan dan Kebudayaan Nomor 97 Tahun 2013, maka dengan mengacu pada asas nullum delictum nulla poena sine praevia lege poenali, maka tindakan $\mathrm{M}, \mathrm{J}, \mathrm{S}$, dan $\mathrm{P}$ telah memenuhi unsur-unsur dalam setiap peraturan perundang-undangan tersebut perihal penyebaran jawaban Ujian Nasional Tahun 2014. 


\section{DAFTAR PUSTAKA}

\section{Buku}

Anggraini, Sukma. "Pembocoran Jawaban Ujian Nasional Oleh Oknum Guru Ditinjau Dari Kitab Undang-Undang Hukum Pidana Dan Undang-Undang Nomor 14 Tahun 2005 Tentang Guru Dan Dosen.” Surabaya, 2007.

Asshiddiqie, Jimly. Teori \& Aliran Penafsiran Hukum Tata Negara. Jakarta: Ind. Hill.Co, 1997.

Finoza, Lamuddin. Komposisi Bahasa Indonesia Uuntuk Mahasiswa Nonjurusan Bahasa. Jakarta: Diksi Insan Mulia, 2005.

Gultom, Maidin. Perlindungan Hukum Terhadap Anak Dan Perempuan. Bandung: Refika Aditama, 2012.

Hardjon. Perlindungan Hukum Terhadap Anak. Jakarta: Eresco, 2007.

Ibrahim, Johnny. Teori Dan Metode Penelitian Hukum Normatif. Malang: Bayumedia Publishing, 2005.

Irmanila, Elmita. "Kredibilitas Penyelenggaraan Ujian Nasional Paper Based Test Dan Ujian Nasional Computer Based Test Pada Mata Pelajaran Matematika Tingkat SMA Dan MA.” Universitas Islam Negeri Sunan Ampel, 2017.

Marzuki, Peter Mahmud. Penelitian Hukum. Surabaya: Kencana, 2005.

Mihradi, Muhammad. Kebebasan Informasi Publik Versus Rahasia Negara. Jakarta: Ghalia Indonesia, 2011.

Nawawi, Hadari, and Mimi Martini. Kebijakan Pendidikan Di Indonesia Ditinjau Dari Sudut Hukum. Pontianak: Gajah Mada University Press, 1994.

Surabaya, Tim Pengajar Hukum Pidana Fakultas Hukum Universitas. "Handout Hukum Pidana.” Surabaya, 2015.

Tilaar, H. A. R. Standarisasi Pendidikan Nasional: Suatu Tinjauan Kritis. Jakarta: Rineka Cipta, 2006. 


\section{Peraturan Perundang-undangan}

Kitab Undang-Undang Hukum Pidana (KUHP)

Undang-Undang Nomor 14 Tahun 2008 tentang Keterbukaan Informasi Publik

Undang-Undang Nomor 20 Tahun 2003 tentang Sistem Pendidikan Nasional

Undang-Undang Nomor 43 Tahun 2009 tentang Kearsipan

Undang-Undang Nomor 35 Tahun 2014 tentang Perubahan Atas Undang-Undang Nomor 23 Tahun 2002 tentang Perlindungan Anak

Peraturan Pemerintah Nomor 19 Tahun 2005 sebagaimana telah dirubah dengan Peraturan Pemerintah Nomor 32 Tahun 2013 tentang Sistem Pendidikan Nasional

Peraturan Menteri Pendidikan dan Kebudayaan Nomor 50 Tahun 2011 tentang Layanan Informasi Publik di Lingkungan Kementerian Pendidikan dan Kebudayaan

Peraturan Menteri Pendidikan dan Kebudayaan Nomor 66 Tahun 2013 tentang Standar Penilaian Pendidikan

Peraturan Menteri Pendidikan dan Kebudayaan Nomor 97 Tahun 2013 tentang Kriteria Kelulusan Peserta Didik dari Satuan Pendidikan dan Penyelenggaraan Ujian Sekolah/Madrash/Pendidikan Kesetaraan dan Ujian Nasional 